\title{
固定術を併用した腰椎椎間板ヘルニア例の検討
}

\author{
福岡市民病院整形外科 \\ 黒 瀬 眞之輔 - 小 山 正 信 \\ 池田 正一・岩 松 陽一郎
}

\section{Treatment of the Lumbar Herniated Disk by Disk Excision and Posterior Lumbar Interbody Fusion}

by

\author{
Shinnosuke Kurose, Masanobu Oyama, Shoichi Ikeda \\ and Yoichirou Iwamatsu \\ Department of Orthopedic Surgery, \\ Fukuoka City Hospital, Fukuoka, Japan
}

\begin{abstract}
From January, 1984 to June, 1990, surgical treatment of the lumbar herniated disk by disk excision and posterior lumbar interbody fusion was performed in 33 consecutive patients by us at the Department of Orthopedic Surgery, Fukuoka City Hospital. Posterior lumbar interbody fusion has been used in conjunction with segmental spine plates (developed by Arthur. D. Steffee) by using transpedicular screw fixation to enhance the osteosynthesis and success rate of interbody fusion. Indicatons for this procedure are spinal instability in a laborer, alignment disorder of the lumbar spine, and recurrent herniated disk of the lumbar spine.

The present study indicates that this method of treatment is recommended to improve overall results for properly selected patients.
\end{abstract}

腰椎椎間板ヘルニアの手術的治療は一般的には, へ ルニア塊の摘出のみで満足すべき結果が得られる. し かし, 術前より罹患椎間に不安定性を有したり,ヘル ニア塊の摘出に際して脊椎支持組織に破綻をきたした り, 同一部位の再発へルニア等では, 除圧操作と共に 固定の併用を考慮する必要がある。我々はかかる症例 に対して積極的に後方からの固定術を併用してきた。 今回, 1984 年 1 月以降 1990 年 6 月迄, 下位腰椎椎間 板ヘルニアに対し，ヘルニア塊の摘出と共に後方から の固定を併用した 33 例の治療結果を調査し, 固定術 併用の適応および手術法を検討した。

\section{対象および方法}

1984 年 1 月以降 1990 年 6 月迄, 172 例の腰椎椎間 板ヘルニアに手術的治療をおこなった. 䍜患椎間およ び手術方法は表 1 に示す.このうち L $3 / 4$ 以下の下位 腰椎例で後方からのへルニア塊の摘出と共に固定を併
用した 33 例を対象とした。手術時年齢は 72 歳から 14 歳, 平均 38.1 歳, 性別は男性 29 例, 女性 4 例, 術後の経過期間は 75 ヶ月から 4 力月, 平均 34.3 ヶ月 であった。

手術方法は後方アプローチによる内側椎間関節切除 を主とした開空で, ヘルニア塊を摘出し, 後述する方 法で同時に後方からの固定をおこなった. 固定椎間は L 4/5 29 例, L $3 / 4,4 / 5$ 3 例, L 4/5, L 5/S 11 例であった。

骨移植法と固定法は後側法固定（以下 PLF）のみ 2 例，PLF と共に instrument を併用したものが 14 例であった．使用した instrumentは hook and rod system として, 北大式 11 例, CD 1 例, Steffee の VSP 1 例であった. 17 例は骨移植を後方経路椎体間 固定（以下 PLIF）とし, instrumentを併用した。 使用した instrumentは pedicular screw system で CD が 5 例, VSP が 12 例であった. 
表 1 腰椎椎間板ヘルニア手術症例

(1984 年 1 月 1990 年 6 月 172 例 $)$

\begin{tabular}{|c|c|c|c|}
\hline \multirow{2}{*}{ 罹患高位 } & \multirow{2}{*}{ 固定なし } & \multicolumn{2}{|c|}{ 固定術併用 } \\
\hline & & 前方 & 後方 \\
\hline $\mathrm{L} 1 / 2$ & & 7例 & \\
\hline $\mathrm{L} 2 / 3$ & 4例 & & 1例 \\
\hline $\mathrm{L} 3 / 4$ & 5例 & & \\
\hline $\mathrm{L} 4 / 5$ & 66例 & 2例 & 29例 \\
\hline L5/S1 & 45例 & & \\
\hline $\mathrm{L} 4 / 5, \mathrm{~L} 5 / \mathrm{S} 1$ & 5例 & & 1例 \\
\hline $\mathrm{L} 3 / 4,4 / 5$ & 3例 & & 3例 \\
\hline 計 & 128例 & 9例 & 34例 \\
\hline (経皮的䯣核摘 & 術 L 4/5 & & \\
\hline
\end{tabular}

表 2 固定術併用を決めた条件

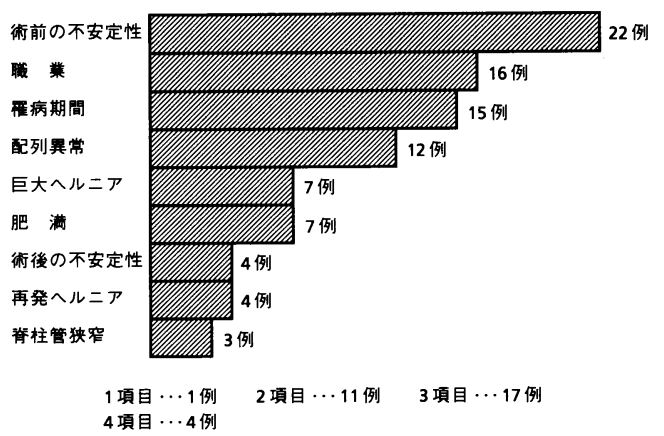

固定術を併用した例の椎間板へルニアのタイプは protrusion が 9 例, うち 2 例は椎体辺縁解離を伴な い, 1 例は外側ヘルニアであった. extrusion は 16 例, sequestration $か ゙ 7$ 例, internal disc disruption が 1 例であった.

ヘルニア塊の摘出と同時に固定術の併用を決めた条 件は表 2 に示すような 9 つの項目が関係した.この条 件のうち 1 項目で適応を決めたものは 1 例, その他は 2 項目以上の条件から固定の併用を決定した.

\section{結果}

日整会腰痛疾患治療成績判定基準による治療成績を 骨移植法別に調査した. PLFでの骨移植によるもの は術前点数 $10.6 \pm 3.9$, 術後点数 $24.4 \pm 3.4$, 改善率 $74.3 \% \pm 19.2$ であった. PLIF による骨移植のものは
術前点数 $10.4 \pm 5.2$, 術後点数 $24.3 \pm 2.7$, 改善率 74.9 $\% \pm 10.7$ であった. 両者間の有意差はなかった. 改 善率が $50 \%$ 以下の例はPLF+北大式後方 instrument の 1 例でみられた以外，他は全て良好な治療成績を獲 得した.

固定術施行にあたり instrument を併用した理由の 1 つである早期離床は, PLFのみの例で平均 15 日で あったのに比べ, hook and rod system で平均 4.6 日, pedicular screw system で平均 3.9 日で所期 の目的が得られた。

術後の骨癒合はPLF のみの 2 例中 1 例で, hook and rod system の12例中 6 例で, pedicular screw system の 19 例全例で得られた。骨癒合の得られな かった例は固定を計った椎間に可動性を残していた.

手術に基づく合併症は hood and rod system で 1 例に硬膜損傷を, pedicular screw system で 1 例に硬膜損傷，他の 1 例で椎弓根損傷をおこした。

術後の合併症はPLF のみの例で, 1 例が偽関節, 1 例は後弯変形を残した. hook and rod system では 6 例が固定椎間に動きを残し， 1 例は後弯変形を 残した. pedicular screw system では神経症状の 悪化が 1 例にみられた。

\section{考察}

腰椎椎間板ヘルニアの手術的療法はヘルニア塊の摘 出のみで満足すべき結果が得られることが多い.しか し，術後も腰痛を主とした症状が残存したり，同一部 位にへルニアの再発をきたしたりする例もある ${ }^{6)}$ 。こ のような例に対しては初回より罹患椎間の固定を併用 した方が, 腰部多数回手術 (MOB) の発生を防止す る意味でも有利であると思われる. 固定術の併用の適 応は諸家によれば，術前より罹患椎間に不安定性のあ るもの，手術侵襲により術後に不安定性をきたすおそ れがあるもの, 配列異常のあるもの, 再発ヘルニア, 腰痛の既往の長いもの, 重労働者等とされてい

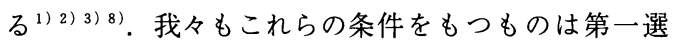
択として固定術を併用しているが，さらに線維輪を伴 なう巨大な脱出へルニア例, 肥満例, 腰部脊柱管狭窄 を合併した例にも, 術後の不安定性が症状の改善に影 響すると考え，固定術を併用してきた。 その結果，1 例を除く全例でほぼ満足すべき結果が得られ，この手 術適応を妥当なものと考える. しかし, 現在は除圧操 
作に基づく脊椎支持組織の損傷は，外側へルニアは外 側アプローチで，中心性巨大ヘルニアは顕微鏡手術に よる椎間関節の温存で, 固定の適応にいれていない. 椎間板ヘルニアに対する固定法は手技の慣れにより 前方法 ${ }^{5)}$ 9), 又は後方法 ${ }^{2)}{ }^{7)}$ が選択されている. 我々 はもっぱら後方法を採用しているが， protruded， internal disc disrupted type は必ずしも後方から の除圧操作の必要がないので，前方法でも満足すべき 結果が得られる。しかし, extruded および sequestrated type では直視下でのヘルニア塊の摘出が必須 であるため, 後方からの除圧操作と後方からの固定が 有利である．再発へルニアに関しては我々の 4 例で, 全て後方からの除圧と後方からの固定が可能であった が，なかには硬膜外に線維性の癒着を伴なう瘕痕組織 のため, PLIFによる固定が困難でPLFによる固定 又は前方固定が必要となる.

骨移植法および instrument の併用については，後 方からの手術といえども，痽患椎間板を完全に除去し てPLIFをおこなう方が，PLFによる例で残存した 椎間板のため疼痛がもたらされるという報告 ${ }^{10)}$ があ るので，骨瘉合および MOB の発生を予防するために 有利と思える. instrument は早期離床と確実な固定 を得るためにも併用した方が利点が多い．使用する instrument として, hook and rod system は固 定性および配列異常の矯正に難点があり, 脊柱管内に instrumentをおくことも問題となる。それに対し， pedicular screw を使用するシステムは固定性もす ぐれ，配列異常の矯正も容易で, instrumentにもと づく神経障害も防止しえる. 従って現在, 我々は pedicular screw system と PLIFによる骨移植を腰椎 椎間板ヘルニア例の固定に使用することが多い.

pedicular screw system のうち CD 法か VSP 法かの選択は，CD 法での手技の煩しさと pedicular screw に伴なう合併症の経験 ${ }^{4)}$ から，現在はもっぱ ら Steffee の VSP system を使用し良好な結果を得 ている.

最後に現在我々が抗こなっている固定法である PLIF + pedicular screw system の利点および欠点をあ げる．利点は直視下での確実な除圧と共に強固な固定 が得られ, 早期離床が可能である. 腰椎椎間板ヘルニ
アの全てのタイプに対応でき，配列異常の矯正も可能 である．欠点はPLIFをおこなう時，神経組織を損 傷する可能性があるという手術手技上の問題と，もう 1 つは硬膜外に癒着のある例で, 後方からの椎間板摘 出が非常に難しいという点である．しかし，手術手技 に習熟すれば合併症も防止でき，確実な除圧と固定が 得られる非常に有用な方法と思われる.

$$
\text { ま と め }
$$

(1)L $3 / 4$ 以下の腰椎椎間板ヘルニアに対し, 後方か らヘルニア塊を除去し同時に固定を 33 例に施行した.

(2) pedicular screw system を併用した例で, 確 実な除圧と骨瘉合が得られた。

(3)労働年㱓で不安定性が術前よりあるもの, 術後に 予測されるもの, 配列異常な伴なうもの, 再発ヘルニ ア等で固定術の併用が望ましい，

(4)手術方法は後方からの除圧と共に PLIF+ pedicular screw systemによる内固定が最も確実であ る.

\section{参 考 文 献}

1) Benini, A.: Lumbar diskektomie with or without spondylodesis? Revival of an old dilemma. Z. Orthop., $127: 276-285,1989$.

2) 遠藤哲ほか: 腰椎椎間板ヘルニアにおける後側方固定 同時併用の適応と問題点について．三豊総合病院雑誌, $10: 41-46,1989$

3) Hoover, N. W.: Indication for fusion at time of removal of intervertebral disc. J. Bone and Joint Surg., 50-A : 189-193, 1968.

4）黑瀬畺之輔ほか：腰椎変性疾患に対する Cotrel-Dubousset 法の検討. 日脊会誌, $1: 147,1990$.

5）西山徹ほか：腰椎椎間板ヘルニアに対する腰椎前方固 定術の治療成績. 臨整外, $21: 871-882,1986$.

6）大澤良充ほか：Failed backの初回手術時の問題点. 整形外科, $38: 1801-1808,1987$.

7) 大村宗久ほか: posterior lumbar interbody fusion の経験. 中部整災雑, $32: 730-731,1989$.

8）関口哲夫ほか: 腰椎椎間板ヘルニアの手術成績. 東北 整災紀要, $33: 1-5,1989$.

9）富永積生ほか: 腰椎椎間板ヘルニアに対する前方固定 術の適応について。整形外科, $38: 1809-1819,1987$.

10) Weatherley, C. R. et al.: Discogenic pain persisting despite solid posterior fusion. J. Bone and Joint Surg., 68-B : 142-143, 1986. 